Vol. 1, No. 2, Juli - Desember 2017

\title{
edureligia
}

\section{INOVASI PEMBELAJARAN PAI DENGAN PENGEMBANGAN \\ MODEL CONSTRUCTIVISM PADA JENJANG PENDIDIKAN \\ DASAR DAN MENENGAH}

\author{
Syaifuddin \\ Program Pascasarjana, Instiut Agama Islam Nurul Jadid, Indonesia
}

\section{Info Artikel}

Sejarah Artikel:

Diterima Mei 2017

Disetujui Juli 2017

Dipublikasikan Sept 2017

Keywords:

Innovation; Constructivism; Islamic Education

\begin{abstract}
So far, the methods used by teachers in the learning process tend to conventional teaching methods which only includes students come, sit, write material that has been written by the teacher on the board, listening to the teacher explaining the material and do the work, using the lecture method. The impact, learning tends to be passive and bored quickly. This kind of learning situation is almost no opportunity for students to express their creativity, so the quality of the quality of learning also becomes low. Constructivism learning model seems to be one of the answers to these problems. Therefore, in this learning model students are preferred. Teaching and learning process in constructivism model student centered more colored than teacher centered. Constructivism model is more empowering for the class as a learning centered not for teaching; not teaching process but learning process. This is in accordance with the curriculum 2013, is autenthic assessment; assessment process and results.
\end{abstract}

PO. Box 1 Paiton Probolinggo, 67291

E-mail: edureligia@gmail.com 


\section{PENDAHULUAN}

Lembaga pendidikan Islam bisa dikategorikan sebagai lembaga industri mulia (noble industri) karena mengemban misi ganda, yaitu profit sekaligus sosial. Misi profit, yaitu untuk mencapai keuntungan, ini dapat dicapai ketika efisiensi dan efektivitas dana bisa tercapai, sehingga pemasukan (income) lebih besar dari biaya operasional. Misi Sosial bertujuan untuk mewariskan dan menginternalisasikan nilai luhur. Misi kedua ini dapat dicapai secara maksimal apabila lembaga pendidikan Islam tersebut memiliki modal human-capital dan sosial capital yang memadai dan juga memiliki tingkat keefektifan dan efesiensi yang tinggi, itulah sebabnya mengelola lembaga pendidikan Islam tidak hanya dibutuhkan profesionalisme yang tinggi, tetapi juga iat-niat suci lainnya, termasuk didalamnya menginovasi berbagai metode pembelajaran

(http://sunardins.blogspot.com).

Pengembangan kreativitas peserta didik seharusnya menjadi bagian tidak terpisahkan dari setiap tujuan mata pelajaran yang diberikan di sekolah, termasuk pelajaran agama Islam (PAI). Membekali para siswa dengan kreativitas, berarti memberi mereka peralatan yang diperlukan untuk hidup dan berkembang bukan hanya pada masa kini, tapi juga untuk masa depan (Suyanto, 2004: 3).

Pandangan klasik yang selama ini berkembang adalah bahwa pengetahuan secara utuh dipindahkan dari pikiran guru ke pikiran anak. Penelitian pendidikan sains pada tahun-tahun terakhir telah mengungkapkan bahwa pengetahuan itu dibangun dalam pikiran seseorang. Pandangan terakhir inilah yang dianut oleh konstruktivisme (Yatim Rianto, 2012: 144). Belajar menurut konstruktivisme merupakan sebuah proses membangun pengetahuan dalam diri peserta didik. Proses inilah yang akan disetting sedemikian rupa dalam sebuah inovasi pembelajaran dengan model konstruktivisme, agar dapat menghasilkan peserta didik yang kreatif.

\section{HAKIKAT PEMBELAJARAN PAI PADA JENJANG PENDIDIKAN DASAR DAN MENENGAH}

Pengertian Pendidikan Agama Islam (PAI)
Dilihat dari segi penamaan suatu mata pelajaran, sebenarnya agama Islam itu bukan suatu mata pelajaran. Islam adalah suatu agama yang berisi ajaran tentang tata hidup yang diturunkan Allah kepada umat manusia melalui para rasul-Nya, sejak dari nabi Adam sampai kepada Nabi Muhammad Saw. Kalau para rasul sebelum nabi Muhammad, ajaran itu berwujud pokok-pokok yang disesuaikan pada kebutuhan waktu itu, maka pada nabi Muhammad SAW ajaran itu disesuaikan dengan kebutuhan umat manusia secara keseluruhan, yang dapat berlaku pada segala masa dan tempat (http://ibnsyam.blogspot.com).

Pendidikan Agama Islam ialah usaha berupa bimbingan dan asuhan terhadap anak didik agar kelak setelah selesai pendidikannya dapat memahami dan mengamalkan ajaran agama Islam serta menjadikannya sebagai pandangan hidup (way of life). Pendidikan Agama Islam juga dapat diartikan sebagai pendidikan yang dilaksanakan berdasarkan ajaran Islam.

Pada hakikatnya tujuan Pendidikan Agama Islam adalah mengembangkan kemampuan anak didik untuk meningkatkan keimanan dan ketaqwaan kepada Allah SWT dalam kehidupan sehari-hari (Baharun, 2017).

Agama mempunyai peranan yang penting dalam kehidupan manusia Pancasila, sebab agama merupakan motivasi hidup dan kehidupan serta merupakan alat pengembangan dan pengendalian diri yang amat penting. Oleh karena itu, agama perlu diketahui, dipahami, dan diamalkan oleh manusia Indonesia agar dapat menjadi dasar kepribadian sehingga ia dapat menjadi manusia yang utuh. Pendidikan agama merupakan bagian pendidikan yang amat penting yang berkenaan dengan aspek-aspek nilai, antara lain akhlak dan keagamaan. Oleh karena itu, pendidikan agama juga menjadi tanggung jawab keluarga, masyarakat dan pemerintah (Daradjat, 1991: 86-87).

Munculnya anggapan-anggapan yang kurang menyenangkan tentang pendidikan agama seperti, Islam diajarkan lebih pada hafalan (padahal Islam penuh dengan nilai-nilai) yang harus dipraktekkan. Pendidikan agama lebih ditekankan pada hubungan formalitas antara hamba dengan Tuhan-Nya; penghayatan nilainilai agama kurang mendapat penekanan dan masih terdapat sederet respon kritis terhadap pendidikan agama. Hal ini disebabkan penilaian kelulusan siswa dalam pelajaran agama diukur dengan berapa banyak hafalan dan mengerjakan ujian tertulis di kelas yang dapat didemonstrasikan oleh siswa (Majid, 2004: 131).

Muhaimin juga menyoroti bahwa berbagai kritik dan sekaligus yang menjadi kelemahan dari 
pelaksanaan pendidikan agama lebih banyak bermuara pada aspek metodologi pembelajaran PAI dan orientasinya yang lebih bersifat normatif, teoritis dan kognitif, termasuk di dalamnya aspek gurunya yang kurang mampu mengaitkan dan berinteraksi dengan mata pelajaran dan guru non-pendidikan agama (Muhaimin, 2007: 26).

Terlepas dari semua kritik itu, pelaksanaan pembelajaran pendidikan agama Islam (PAI) memang banyak kelemahannya. Kelemahan itu tidak hanya terdapat pada sisi fisik (hardtech) seperti bahan ajar, media, tetapi juga pada sisi softech-nya seperti keterampilan guru PAI dalam mengaplikasikan model-model pembelajaran.

Peraturan Pemerintah (PP) No. 55 tahun 2007 menjelaskan bahwa pendidikan agama adalah pendidikan yang memberikan pengetahuan dan membentuk sikap, kepribadian, dan keterampilan peserta didik dalam mengamalkan ajaran agamanya, yang dilaksanakan sekurang-kurangnya melalui mata pelajaran/kuliah pada semua jalur, jenjang, dan jenis pendidikan.

Sedangkan Pendidikan keagamaan adalah pendidikan yang mempersiapkan peserta didik untuk dapat menjalankan peranan yang menuntut penguasaan pengetahuan tentang ajaran agama dan/atau menjadi ahli ilmu agama dan mengamalkan ajaran agamanya.

\section{Fungsi dan Tujuan Pendidikan Agama dan} keagamaan

Dalam PP. No. 55 tahun 2007 pasal 2 ayat 1 dan 2 dijelaskan bahwa Pendidikan agama berfungsi membentuk manusia Indonesia yang beriman dan bertakwa kepada Tuhan Yang Maha Esa serta berakhlak mulia dan mampu menjaga kedamaian dan kerukunan hubungan inter dan antarumat beragama. Sedangkan tujuan pendidikan agama untuk berkembangnya kemampuan peserta didik dalam memahami, menghayati, dan mengamalkan nilai-nilai agama yang menyerasikan penguasaannya dalam ilmu pengetahuan, teknologi dan seni.

Pendidikan keagamaan berfungsi mempersiapkan peserta didik menjadi anggota masyarakat yang memahami dan mengamalkan nilai-nilai ajaran agamanya dan/atau menjadi ahli ilmu agama. Pendidikan keagamaan bertujuan untuk terbentuknya peserta didik yang memahami dan mengamalkan nilai-nilai ajaran agamanya dan/atau menjadi ahli ilmu agama yang berwawasan luas, kritis, kreatif, inovatif, dan dinamis dalam rangka mencerdaskan kehidupan bangsa yang beriman, bertakwa, dan berakhlak mulia.

Jika dilihat dari fungsi dan tujuan PAI dalam PP 55 tadi, tampak bahwa pembelajaran PAI di sekolah berfungsi untuk membentuk manusia muslim yang dapat "menafasi" profesinya. PAI harus dapat membingkai pikiran, perasaan juga perilaku peserta didik, sehingga apa pun profesinya, nafasnya tetap muslim; aturan yang membingkai dirinya adalah ajaran Islam. Kekuatan untuk menafasi profesi itu terletak pada aspek afeksi.

Dalam taksonomi

Bloom (http://noviakimiapasca. wordpress.com), tujuan pendidikan diklasifikasikan menjadi tiga ranah, yaitu kognitif, afektif, dan psikomotor. Ranah kognitif meliputi fungsi memproses informasi, pengetahuan dan keahlian mentalitas. Ranah afektif meliputi fungsi yang berkaitan dengan sikap dan perasaan. Sedangkan ranah psikomotorik berkaitan dengan fungsi manipulatif dan kemampuan fisik.

Ranah kognitif menggolongkan dan mengurutkan keahlian berpikir yang menggambarkan tujuan yang diharapkan. Proses berpikir mengekspresikan tahap-tahap kemampuan yang harus siswa kuasai sehingga dapat menunjukan kemampuan mengolah pikirannya, sehingga mampu mengaplikasikan teori ke dalam perbuatan. Mengubah teori ke dalam keterampilan terbaiknya, sehingga dapat menghasilkan sesuatu yang baru sebagai produk inovasi pikirannya.

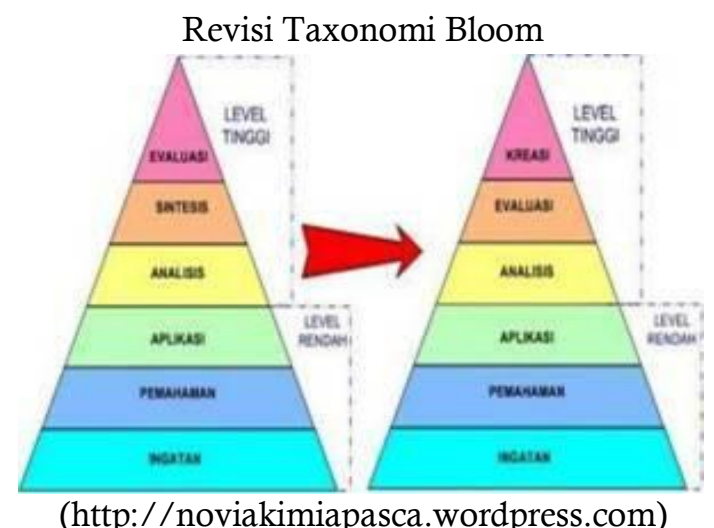

Ranah afektif berkenaan dengan sikap dan nilai. Tipe hasil belajar afektif tampak pada siswa dalam berbagai tingkah laku seperti perhatiannya terhadap pelajaran, disiplin, motivasi belajar, menghargai guru dan teman sekelas, kebiasaan 
belajar, dan hubungan sosial. Beberapa jenis kategori ranah afektif sebagai hasil belajar:

\section{Menerima (Receiving)}

Menerima artinya kemauan untuk memperlihatkan suatu kegiatan atau menerima merupakan kepekaan dalam menerima rangsangan dari luar yang datang pada siswa dalam bentuk situasi.

\section{Menanggapi (Responding)}

Menanggapi yakni reaksi yang diberikan oleh seseorang terhadap stimulus yang datang dari luar. Hal ini mencakup ketepatan reaksi, perasaan, kepuasan dalam menjawab stimulus dari luar yang datang kepada dirinya.

\section{Penilaian (Valuing)}

Penilaian atau evaluasi merupakan penentuan derajat kualitas berdasarkan indikator yang ditetapkan (Baharun, 2016). Konsep nilai yang abstrak ini sebagian merupakan hasil dari penilaian (valuing) atau asesmen (assessment) dan juga merupakan hasil sosial yang perlahan-lahan telah terserap dalam diri siswa (internalized) atau diterima dan digunakan siswa sebagai kriteria untuk melakukan penilaian. Unsur utama yang terdapat pada perilaku dalam melakukan penilaian adalah bahwa perilaku tersebut dimotivasi, bukan oleh keinginan untuk menjadi siswa yang patuh, namun oleh komitmen terhadap nilai yang mendasari munculnya perilaku.

\section{Mengorganisasikan (Organization)}

Mengorganisasikan

adalah pengembangan dari nilai ke dalam satu sistem organisasi, termasuk hubungan satu nilai dengan nilai yang lain, pemantapan dan prioritas nilai yang telah dimilikinya. Kemampuan internal dari mengorganisasikan ini adalah siswa mampu membentuk sistem nilai, mampu bertanggung jawab terhadap nilai baru.

Karakteristik nilai/menjadikan pola hidup (Characteriszation by a value)

Karakteristik nilai ialah keterpaduan semua sistem nilai yang telah dimiliki seseorang yang mempengaruhi pola kepribadian dan tingkah laku. Tingkah laku siswa menetap, konsisten dan dapat diramalkan, sehingga tingkah lakunya itu menjadi ciri khas atau karakteristik siswa itu.
Ranah psikomotor adalah ranah yang berkaitan dengan keterampilan (skill) atau kemampuan bertindak setelah seseorang menerima pengalaman belajar tertentu. Tingkat diusulkan adalah:

Persepsi, yaitu Kemampuan untuk menggunakan isyarat sensorik untuk memandu aktivitas motorik; 2. Kesiapan untuk bertindak. Ini mencakup, fisik, mental dan emosional set. Ketiga set disposisi yang mentakdirkan seseorang tanggapan terhadap situasi yang berbeda; 3 . Dipandu Respon Tahap awal dalam mempelajari keterampilan yang kompleks yang mencakup imitasi dan trial and error. Kecukupan kinerja dicapai dengan berlatih; 4. Mekanisme, yaitu tahap peralihan dalam mempelajari keterampilan yang kompleks. Tanggapan telah menjadi kebiasaan dan gerakan dapat dilakukan dengan beberapa kepercayaan dan kemampuan; Kompleks terbuka Respon, yaitu Kinerja terampil tindakan motor yang melibatkan pola gerakan yang kompleks. Kemahiran diindikasikan oleh, akurat, dan sangat terkoordinasi kinerja cepat, membutuhkan minimal energi. Kategori ini berisi melakukan tanpa ragu-ragu, dan kinerja otomatis; 6 . Adaptasi, yaitu Keterampilan yang dikembangkan dengan baik dan orang tersebut dapat memodifikasi pola pergerakan untuk memenuhi persyaratan khusus; dan 7. Originasi Membuat pola gerakan baru agar sesuai dengan situasi tertentu atau masalah khusus. Hasil pembelajaran menekankan kreativitas berdasarkan kemampuan mengembangkan keterampilan tinggi (http://noviakimiapasca.wordpress.com).

Pembelajaran PAI sejatinya memiliki kekuatan pada aspek afeksi (afektif), dan psikomotor, sehingga target pembelajaran PAI di sekolah adalah bagaimana agama dalam diri anak dapat menafasi profesinya. Dengan kata lain, PAI di sekolah dapat membentuk anak yang memiliki perilaku profesi (professional), tetapi nafasnya agama (Islami). Ini yang menjadi tantangan para guru PAI di sekolah. Dalam rangka mewujudkan target tersebut, maka pembelajaran PAI perlu disetting sedemikian rupa. Salah satunya adalah menggunakan pendekatan saintific, seperti yang mendasari model konstruktivisme.

\section{Signifikansi Pembelajaran PAI pada Jenjang Pendidikan Dasar dan Menengah}

Pendidikan dasar merupakan jenjang pendidikan yang melandasi jenjang pendidikan menengah. Pendidikan dasar berbentuk sekolah dasar (SD) dan madrasah ibtidaiyah (MI) atau bentuk lain yang sederajat serta sekolah menengah pertama (SMP) dan madrasah tsanawiyah (MTs), atau bentuk lain yang 
sederajat. (UU no 20 tahun 2003 pasal 17 ayat 1-3).

Undang-undang Nomor 2 Tahun 1989 tentang Sistem Pendidikan Nasional menetapkan bahwa pendidikan dasar diselenggarakan untuk mengembangkan sikap dan kemampuan serta memberikan pengetahuan dan keterampilan dasar yang diperlukan untuk hidup dalam masyarakat serta mempersiapkan peserta didik yang memenuhi persyaratan untuk mengikuti pendidikan menengah.

Berkenaan dengan pembedaan jalur dan sistem pendidikan nasional dalam jalur pendidikan sekolah dan jalur pendidikan luar sekolah, pendidikan dasar dapat diselenggarakan baik pada jalur pendidikan sekolah maupun pada jalur pendidikan luar sekolah. Berkenaan dengan pemanfaatan perkembangan teknologi, pendidikan dasar diselenggarakan dalam bentuk kegiatan belajar-mengajar di sekolah maupun dalam bentuk program pendidikan jarak jauh.

Mengingat bahwa pendidikan dasar dapat diselenggarakan baik oleh Pemerintah, dalam hal ini Departemen Pendidikan Nasional, Departemen Dalam Negeri dan Departemen Agama, maupun oleh masyarakat, dalam hal ini yayasan atau badan yang bersifat sosial, Pendidikan dasar yang diatur dalam Peraturan Pemerintah merupakan pendidikan yang diselenggarakan selama sembilan tahun sebagaimana diatur dalam UU no 20 tahun 2003 tentang Sistem Pendidikan Nasional yang terdiri atas program enam tahun di Sekolah Dasar dan program tiga tahun di Sekolah Lanjutan Tingkat Pertama. Sekolah Lanjutan Tingkat Pertama dimaksud bukan merupakan jenjang dalam pendidikan di jalur sekolah tetapi merupakan bagian dalam jenjang pendidikan dasar.

Disamping itu, Pemerintah juga memberi peluang baik bagi satuan pendidikan dasar maupun bagi peneliti dan pengembang di bidang pendidikan untuk melakukan penelitian dan/atau uji-coba untuk mengembangkan gagasan baru atau dalam rangka penyempurnaan sistem pendidikan nasional dengan tidak mengurangi kelangsungan penyelenggaraan pendidikan pada satuan pendidikan dasar yang bersangkutan (http://journal424. wordpress.com).
Pendidikan dasar bertujuan untuk memberikan bekal kemampuan dasar kepada peserta didik untuk mengembangkan kehidupannya sebagai pribadi, anggota masyarakat, warga negara dan anggota umat manusia serta mempersiapkan peserta didik untuk mengikuti pendidikan menengah. (PP no 28 tahun 1990 pasal 3).

Sementara itu, tujuan pendidikan tingkat satuan pendidikan menengah dirumuskan mengacu kepada tujuan umum pendidikan sebagai berikut.

a. Tujuan pendidikan menengah adalah meningkatkan kecerdasan, pengetahuan, kepribadian, akhlak mulia, serta keterampilan untuk hidup mandiri dan mengikuti pendidikan lebih lanjut.

b. Tujuan pendidikan menengah kejuruan adalah meningkatkan kecerdasan, pengetahuan, kepribadian, akhlak mulia, serta keterampilan untuk hidup mandiri dan mengikuti pendidikan lebih lanjut sesuai dengan kejuruannya (BSNP, 200).

c. Karakteristik Siswa Pendidikan Menengah; Anak pada usia SMA/Remaja berada pada masa transisi atau peralihan. Masa ini sering juga disebut dengan masa puber. Anak pada masa ini tengah mengalami proses peralihan dari masa anak-anak menuju masa dewasa sehingga dibilang anak-anak sudah tidak pantas lagi namun dibilang dewasa pun belum tepat (http//:direkrorifip.com).

Salah satu ungkapan fisikawan terkenal, Albert Einstein adalah: "science without religion is blind, religion without science is lame" (ilmu tanpa agama buta, agama tanpa ilmu lumpuh). Seorang Einstein menyadari bahwa antara ilmu dan agama memiliki kaitan yang erat sekali dan amat dibutuhkan dalam kehidupan manusia. Jauh sebelum Einstein, agama Islam juga memandang penting antara ilmu dan agama. Bahkan wahyu pertama yang diterima Nabi Muhammad SAW justru mengandung perintah untuk menguasai ilmu dengan landasan iman (Qs.

(http://isyemetriah.blogspot.com). al-'Alaq/96:1-5)

Pentingnya ilmu dan agama juga terlihat jelas dalam Sistem Pendidikan Nasional (Sisdiknas). Dalam pasal 3 UU Sisdiknas tahun 2003 ditegaskan bahwa tujuan pendidikan nasional adalah "...untuk berkembangnya potensi peserta didik agar menjadi manusia yang beriman dan bertakwa kepada Tuhan Yang Maha Esa, berakhlak mulia, sehat, berilmu, cakap, kreatif mandiri, dan menjadi warga negara yang demokratis serta bertanggung jawab". Kriteria pertama dan utama dalam rumusan tujuan tersebut adalah manusia yang beriman dan bertakwa kepada Tuhan YME serta berakhlak 
mulia. Rumusan ini menunjukkan sistem pendidikan kita justru meletakkan agama lebih dahulu dari pada ilmu pengetahun. Agama adalah "Core" yang akan menyeimbangkan akal dan emosional seseorang, sehingga dapat menjadi insan berakhlak mulia seperti yang dicitacitakan oleh pendidikan nasional.

Penempatan ilmu sesudah agama sesungguhnya logis dan relevan dengan karakter bangsa yang berkeyakinan terhadap Tuhan Yang Maha Esa. Ketika ilmu yang lebih diutamakan akan dikhawatirkan lahirnya orang-orang pintar tetapi tidak beriman. Meskipun pembentukan dan pengembangan karakter dapat dilakukan di rumah melalui bimbingan orang tua dan lingkungan sekitar (Islam, 2017). Akibatnya, kepintaran mereka bisa menghasilkan mudharat yang lebih besar dari pada manfaat. Oleh karena itu, Pendidikan Agama Islam (PAI) memiliki peran yang sangat strategis dalam mewujudkan rumusan tujuan pendidikan di atas.

Permendiknas Nomor 41 tahun 2007: Mencerminkan Konstruktivisme

Permendiknas nomor 41 tahun 2007 ini mengatur tentang standar proses pendidikan. Standar proses mencakup perencanaan proses pembelajaran, pelaksanaan proses pembelajaran, penilaian hasil pembelajaran, dan pengawasan proses pembelajaran untuk ter-laksananya proses pembelajaran yang efektif dan efisien. Pada awalnya hal ini adalah untuk menjembatani beragamnya budaya, geografis dan ketersediaan agar semua proses pembelajaran dapat berlangsung dengan standar tertentu yang dipercaya semuanya.

Tentunya tanpa meninggalkan proses pembelajaran pada setiap satauan pendidikan dasar dan menengah yang mengedepankan interaksi, inspiratif, menyendangkan, menantang, memotivasi keaktifan partisipasi, ruang lega untuk berkreasi, memunculkan idea gagasan yang original selaras dengan bakat, minat, fisik dan suasana psikologi peserta didik.

Sesuai dengan amanat Peraturan Pemerintah Nomor 19 tahun 2005 tentang Standar Nasional Pendidikan salah satu standar yang harus dikembangkan adalah standar proses. Standar proses adalah standar nasional pendidikan yang berkaitan dengan pelaksanaan pembelajaran pada satuan pendidikan untuk mencapai kompetensi lulusan. Standar proses berisi kriteria minimal proses pembelajaran pada satuan pendidikan dasar dan menengah di seluruh wilayah hukum Negara Kesatuan Republik Indonesia. Standar proses ini berlaku untuk jenjang pendidikan dasar dan menengah pada jalur formal, balk pada sistem paket maupun pada sistem kredit semester.

Salah satu prinsip dalam reformasi pendidikan adalah pendidikan diselenggarakan sebagai proses pembudayaan dan pemberdayaan peserta didik yang berlangsung sepanjang hayat. Dalam proses tersebut diperlukan guru yang memberikan keteladanan, membangun kemauan, dan mengembangkan potensi dan kreativitas peserta didik. Implikasi dari prinsip ini adalah pergeseran paradigma proses pendidikan, yaitu dari paradigma pengajaran ke paradigma pembelajaran. Pembelajaran adalah proses interaksi peserta didik dengan guru dan sumber belajar pada suatu lingkungan belajar. Proses pembelajaran perlu direncanakan, dilaksanakan, dinilai, dan diawasi agar terlaksana secara efektif dan efisien. Menuju visi pendidikan nasional yaitu terwujudnya sistem pendidikan sebagai pranata sosial yang kuat dan berwibawa untuk memberdayakan semua warga negara Indonesia berkembang menjadi manusia yang berkualitas sehingga mampu dan proaktif menjawab tantangan zaman yang selalu berubah.

\section{MODEL CONCTRUCTIVISM (KONSTRUKTIVISME) DALAM PEMBELAJARAN}

\section{Memahami Model Construktivism (Konstruktivisme)}

Kontruksi berarti bersifat membangun, dalam konteks filsafat pendidikan, Konstruktivisme adalah suatu upaya membangun tata susunan hidup yang berbudaya modern. Konstruktivisme merupakan landasan berfikir (filosofi) pembelajaran konstektual yaitu bahwa pengetahuan dibangun oleh manusia sedikit demi sedikit, yang hasilnya diperluas melalui konteks yang terbatas dan tidak sekonyongkonyong. Pengetahuan bukanlah seperangkat fakta-fakta, konsep, atau kaidah yang siap untuk diambil dan diingat. Manusia harus mengkontruksi pengetahuan itu dan memberi makna melalui pengalaman nyata (http://wordpress.com).

Esensi dari teori konstruktivis adalah ide bahwa siswa sendiri yang menemukan dan mentransformasikan sendiri suatu informasi kompleks apabila mereka menginginkan informasi itu menjadi miliknya (Trianto, 2012: 74). Dengan kata lain, konstruktivisme adalah suatu aliran filsafat yang berasumsi bahwa 
pengetahuan seseorang bukanlah hasil transfer dari guru kepada peserta didik, tetapi sebuah proses yang "dibentuk" oleh peserta didik itu sendiri dengan bantuan pengalaman dan interaksinya dengan lingkungan.

Menurut konstruktivisme, pengetahuan bukanlah suatu tiruan dari kenyataan (realitas). Pengetahuan bukanlah gambaran dari dunia kenyataan yang ada. Pengetahuan selalu akibat dari suatu konstruksi kognitif kenyataan melalui kegiatan seseorang. Seseorang membentuk skema, konsep, nilai dan struktur pengetahuan yang diperlukan untuk pengetahuan. Maka pengetahuan bukanlah tentang dunia lepas dari pengamatan, tetapi merupakan ciptaan manusia yang mengkonstruksi pengalaman atau dunia sejauh dialaminya (Suparno: 162).

Dari keterangan diatas dapat ditarik kesimpulan bahwa teori ini mendorong keaktivan peserta didik untuk belajar menemukan sendiri kompetensi, pengetahuan atau teknologi guna mengembangkan dirinya sendiri.

Konstruktivisme didefinisikan sebagai pembelajaran yang bersifat generatif, yaitu tindakan mencipta sesuatu makna dari apa yang dipelajari. Beda dengan aliran behavioristik yang memahami hakikat belajar sebagai kegiatan yang bersifat mekanistik antara stimulus respon, kontruktivisme lebih memahami belajar sebagai kegiatan manusia membangun atau menciptakan pengetahuan dengan memberi makna pada pengetahuannya sesuai dengan pengalamanya. Konstruktivisme sebenarnya bukan merupakan gagasan yang baru, apa yang dilalui dalam kehidupan kita selama ini merupakan himpunan dan pembinaan pengalaman demi pengalaman. Ini menyebabkan seseorang mempunyai pengetahuan dan menjadi lebih dinamis.

Von Glasersfeld mengatakan bahwa konstruktivisme adalah salah satu filsafat pengetahuan yang menekankan bahwa pengetahuan kita adalah konstruksi (bentukan) kita sendiri. Pengetahuan itu dibentuk oleh struktur konsepsi seseorang sewaktu berinteraksi dengan lingkungannya (Suparno: 162).

Revolusi konstruktivisme memiliki akar yang kuat dalam sejarah pendidikan. Konstruktivisme lahir dari gagasan Piaget dan Vigotsky yang keduanya menekankan pada perubahan kognitif akan terjadi jika konsepkonsep yang telah dipahami sebelum diolah melalui suatu proses ketidakseimbangan dalam upaya memahami informasi-informasi baru. Keduanya juga menekankan adanya hakikat sosial dan belajar. Keduanya menyarankan untuk menggunakan kelompok-kelompok belajar dengan kemampuan anggota kelompok yang berbeda-beda untuk mengupayakan perubahan konseptual.

Kegiatan pembelajaran yang selama ini berlangsung, yang berpijak pada teori behavioristik, banyak didominasi oleh guru. Guru menyampaikan materi pelajaran dengan ceramah, dengan harapan siswa dapat memahaminya dan memberikan respon sesuai dengan materi yang diceramahkan. Alternatifalternatif perbedaan interpretasi di antara siswa terhadap fenomena sosial yang kompleks tidak dipertimbangkan. Pengajaran didasarkan pada gagasan atau konsep-konsep yang sudah dianggap pasti atau baku, dan siswa harus memahaminya. Pengkonstruksian pengetahuan baru oleh siswa tidak dihargai sebagai kemampuan penguasaan pengetahuan.

Berbeda dengan bentuk pembelajaran di atas, pembelajaran konstruktivistik membantu siswa menginternalisasi dan mentransformasi informasi baru. Transformasi terjadi dengan menghasilkan pengetahuan baru yang selanjutnya akan membentuk struktur kognitif baru. Secara rinci perbedaan karakteristik antara pembelajaran tradisional (behavioristik) dengan pembelajaran konstruktivistik adalah sebagai berikut (Budiningsih, 2012: 63):

\section{Tabel 1}

Perbedaan Pembelajaran Behavioristik dan Konstruktivistik

\begin{tabular}{|l|l|}
\hline \multicolumn{1}{|c|}{$\begin{array}{c}\text { Pembelajaran } \\
\text { Behavioristik }\end{array}$} & \multicolumn{1}{c|}{$\begin{array}{c}\text { Pembelajaran } \\
\text { Konstruktivistik }\end{array}$} \\
\hline $\begin{array}{l}\text { Kurikulum } \\
\text { disajikan dari } \\
\text { bagian-bagian } \\
\text { menuju keseluruhan } \\
\text { dengan } \\
\text { menekankan pada } \\
\text { ketrampilan- } \\
\text { ketrampilan dasar. }\end{array}$ & $\begin{array}{l}\text { Kurikulum } \\
\text { disajikan mulai } \\
\text { dari keseluruhan } \\
\text { menuju ke bagian- } \\
\text { bagian, dan lebih } \\
\text { mendekatkan } \\
\text { pada konsep } \\
\text { konsep yang lebih } \\
\text { luas. }\end{array}$ \\
\hline $\begin{array}{l}\text { Pembelajaran } \\
\text { sangat taat pada } \\
\text { kurikulum yang } \\
\text { telah ditetapkan. }\end{array}$ & $\begin{array}{l}\text { Pembelajaran } \\
\text { lebih menghargai } \\
\text { pada pemunculan } \\
\text { pertanyaan dan } \\
\text { ide-ide siswa }\end{array}$ \\
\hline $\begin{array}{l}\text { Kegiatan kurikuler } \\
\text { lebih banyak }\end{array}$ & $\begin{array}{l}\text { Kegiatan kurikuler } \\
\text { lebih banyak }\end{array}$ \\
\hline
\end{tabular}




\begin{tabular}{|c|c|}
\hline $\begin{array}{l}\text { mengandalkan pada } \\
\text { buku teks dan buku } \\
\text { kerja }\end{array}$ & $\begin{array}{l}\text { mengadalkan } \\
\text { sumber-sumber } \\
\text { data primer dan } \\
\text { manupulasi bahan }\end{array}$ \\
\hline $\begin{array}{l}\text { Siswa-siwa } \\
\text { dipandang sebagai } \\
\text { "Kertas kosong" } \\
\text { yang dapat digoresi } \\
\text { informasi oleh guru, } \\
\text { dan guru-guru pada } \\
\text { umumnya } \\
\text { menggunakan cara } \\
\text { didaktik dalam } \\
\text { menyampaikan } \\
\text { informasi kepada } \\
\text { siswa }\end{array}$ & $\begin{array}{l}\text { Siswa dipandang } \\
\text { sebagai pemikir- } \\
\text { pemikir yang } \\
\text { dapat } \\
\text { memunculkan } \\
\text { teori-teori tentang } \\
\text { dirinya. }\end{array}$ \\
\hline $\begin{array}{l}\text { Penilaian hasil } \\
\text { belajar atau } \\
\text { pengetahuan siswa } \\
\text { dipandang sebagai } \\
\text { bagian dari } \\
\text { pembelajaran dan } \\
\text { biasanya dilakukan } \\
\text { pada akhir pelajaran } \\
\text { dengan cara testing }\end{array}$ & $\begin{array}{l}\text { Pengukuran } \\
\text { proses dan hasil } \\
\text { belajar siswa } \\
\text { terjalin di dalam } \\
\text { kesatuan kegiatan } \\
\text { pembelajaran, } \\
\text { dengan cara guru } \\
\text { mengamati hal-hal } \\
\text { yang sedang } \\
\text { dilakuan siswa, } \\
\text { serta melalui } \\
\text { tugas-tugas } \\
\text { pekerjaan }\end{array}$ \\
\hline $\begin{array}{l}\text { Siswa-siswa } \\
\text { biasanya bekerja } \\
\text { sendiri-sendiri, } \\
\text { tanpa ada group } \\
\text { process dalam belaj }\end{array}$ & $\begin{array}{l}\text { Siswa-siswa } \\
\text { banyak belajar } \\
\text { dan bekerja di } \\
\text { dalam group process }\end{array}$ \\
\hline
\end{tabular}

\section{Implikasi Konstruktivisme dalam Pembelajaran}

Jika ada pertanyaan: "Bagaimana kita menjadi tahu apa yang kita ketahui?"Maka jawaban pertama menyatakan bahwa pengetahuan secara utuh dipindahkan dari pikiran guru ke pikiran anak. Inilah jawaban yang umum dianut dunia pendidikan hingga sekarang, terutama di Negara kita. Jawaban kedua adalah "Pengetahuan dibangun dalam pikiran anak". Ini adalah jawaban para konstruktivis (konstruktivisme).

Salah satu teori atau pandangan yang sangat terkenal berkaitan dengan teori belajar konstruktivisme adalah teori perkembangan mental Piaget. Teori ini biasa juga disebut teori perkembangan intelektual atau teori perkembangan kognitif. Teori belajar tersebut berkenaan dengan kesiapan anak untuk belajar, yang dikemas dalam tahap perkembangan intelektual dari lahir hingga dewasa.
Setiap tahap perkembangan intelektual yang dimaksud dilengkapi dengan ciri-ciri tertentu dalam mengkonstruksi ilmu pengetahuan. Misalnya, pada tahap sensori motor anak berpikir melalui gerakan atau perbuatan (Russefendi, 1998: 132).

Umumnya belajar dipahami sebagai suatu proses usaha yang dilakukan oleh seseorang untuk memperoleh suatu perubahan tingkah laku yang baru secara keseluruhan, sebagai hasil pengalamannya sendiri dalam interaksi dengan lingkungannya (Slameto, 2003: 2). Secara konseptual, proses belajar jika dipandang dari pendekatan kognitif, bukan sebagai perolehan informasi yang berlangsung satu arah dari luar ke dalam diri siswa, melainkan sebagai pemberian makna oleh siswa kepada pengalamannya melalui proses asimilasi dan akomodasi yang bermuara pada pemutakhiran struktur kognitifnya.

Kegiatan belajar lebih dipandang dari segi prosesnya daripada segi perolehan pengetahuan dari fakta-fakta yang terlepas-lepas. Proses tersebut berupa "...constructing and restructuring of knowledge and skills (schemata) within the individual in a complex network of increasing conceptual consistency...". Pemberian makna terhadap objek dan pengalaman oleh individu tersebut tidak dilakukan secara sendiri-sendiri oleh siswa, melainkan melalui interaksi dalam jaringan social yang unik, yang terbentuk dalam budaya kelas maupun di luar kelas (Budiningsih, 2012: 58).

Selanjutnya, Piaget yang dikenal sebagai konstruktivis pertama (Ratna, 2002: 152) menegaskan bahwa pengetahuan tersebut dibangun dalam pikiran anak melalui asimilasi dan akomodasi. Asimilasi adalah penyerapan informasi baru dalam pikiran. Sedangkan, akomodasi adalah menyusun kembali struktur pikiran karena adanya informasi baru, sehingga informasi tersebut mempunyai tempat. Pengertian tentang akomodasi yang lain adalah proses mental yang meliputi pembentukan skema baru yang cocok dengan ransangan baru atau memodifikasi skema yang sudah ada sehingga cocok dengan rangsangan itu.

Menurut pandangan konstruktivistik, belajar merupakan suatu proses pembentukan pengetahuan. Pembentukan ini harus dilakukan oleh si belajar. Ia harus aktif melakukan kegiatan, aktif berpikir, menyusun konsep dan memberi makna tentang hal-hal yang sedang dipelajari. Karena proses belajar merupakan suatu proses organik yang di dalamnya seseorang menemukan sesuatu, bukan suatu proses mekanik sekedar mengumpulkan fakta, maka dalam pandangan 
konstruktivisme proses belajar seseorang mengalami perubahan konsep (Annurohman, 2010: 20).

Dalam belajar model konstruktivisme, peranan guru adalah membantu agar proses pengkonstruksian pengetahuan yang sedang dilakukan siswa dapat berjalan dengan lancar. Guru tidak mentransfer pengetahuan telah yang dimilikinya, melainkan membantu siswa untuk membentuk pengetahuannya sendiri (Budingsih: 59). Implikasi bagi guru dalam mengembangkan tahap konstruktivisme ini terutama dituntut kemampuan untuk membimbing siswa mendapatkan makna dari setiap konsep yang dipelajarinya (Rusman, 2013: 193194).

Mengajar berarti berpartisipasi dengan peserta didik dalam membentuk pengetahuan, membuat makna, mempertanyakan kejelasan, bersikap kritis, mengadakan justifikasi. Jadi, mengajar adalah suatu bentuk belajar sendiri. Menurut prinsip konstruktivisme, seorang pendidik mempunyai peran sebagai mediator dan fasilitator yang membantu agar proses belajar peserta didik berjalan dengan baik. Maka tekanan diletakkan pada peserta didik yang belajar dan bukan pada pendidik yang mengajar (Sutarjio: 187).

Untuk itu, menurut Trianto, dalam pembelajaran model konstruktivisme tugas guru adalah memfasilitasi proses belajar tersebut dengan cara:

a. Menjadikan pengetahuan bermakna dan relevan bagi siswa,

b. Memberi kesempatan siswa menemukan dan menerapkan idenya sendiri, dan

c. Menyadarkan siswa agar menerapkan strategi mereka sendiri dalam belajar (Trianto: 109).

Kaum konstruktivis berpendapat bahwa pendidik perlu membiarkan peserta didik menemukan cara yang paling cocok dalam memecahkan persoalan. Peserta didik kadang suka mengambil jalan yang tidak konvensional untuk memecahkan suatu soal. Bila seorang pendidik tidak menghargai cara penemuan mereka, ini berarti menyalahi sejarah perkembangan ilmu, yang juga dimulai dari kesalahan (Sutrajo: 189).
Secara lebih rinci, Aunurrahman (2010: 23-24) menjelaskan bahwa dalam kegiatan pembelajaran yang berparadigma konstruktivisme, fungsi guru sebagai mediator dan fasilitator dapat dijabarkan dalam beberapa wujud tugas sebagai berikut:

a. Menyediakan pengalaman belajar yang memungkinkan siwa bertanggung jawab dalam membuat rancangan, proses dan penelitian. Dalam fungsi ini tentu saja caracara mengajar dengan memberikan informasi, penjelasan yang dominan dari guru melalui metode ceramah cenderung kurang memberikan pengalaman belajar yang optimal kepada siswa. Kegiatan pembelajaran hendaknya dapat memberikan kesempatan secara luas kepada siswa agar mereka dapat mengembangkan kemampuan berpikir, memberi kesempatan untuk tumbuh dan berkembangnya inisiatif dan kreativitas sesuai dengan modalitas belajarnya masing-masing.

b. Memberikan kegiatan yang merangsang keingintahuan siswa dan membantu mereka untuk mengekspresikan gagasan-gagasannya serta ide-ide ilmiahnya.

c. Memonitor, mengevaluasi dan menunjukkan apakah pemikiran-pemikiran siswa dapat didorong secara aktif.

Jadi, ada beberapa prinsip dasar pembelajaran konstruktivisme, yaitu:

a. Pengetahuan dibangun oleh siswa secara aktif

b. Tekanan prroses belajar terletak pada siswa

c. Mengajar adalah membantu siswa belajar

d. Penekanan dalam proses belajar lebih kepada proses bukan hasil akhir

e. Kurikulum menekankan partisipasi siwa

f. Guru adalah fasilitator (Aunnurahman, 2010: 25)

Dengan demikian, pada model konstruktivisme ini peranan "Proses" dalam pembelajaran jauh lebih penting daripada "Hasil". Proses inilah yang harus dirancang sedemikian rupa oleh guru agar peserta didik dapat merasakan makna. Pembelajaran akan dirasakan memiliki makna apabila secara langsung atau tidak langsung berhubungan dengan pengalaman sehari-hari yang dialami oleh peserta didik sendiri. Oleh sebab itu, model konstruktivisme ini sangat erat kaitannya dengan pendekatan kontekstual (CTL) dan metode-metode pembelajaran seperti inquiry (menemukan), questioning (bertanya), learning 
community (masyarakat belajar), dengan penilaian sebenarnya (Authentic Assessment).

Disahkan dan diberlakukannya UndangUndang Nomor 20 tahun 2003 tentang Sistem Pendidikan Nasional, oleh banyak kalangan dianggap sebagai titik awal kebangkitan pendidikan nasional, termasuk pendidikan Islam di dalamnya. Hal ini karena secara eksplisit UU tersebut menyebut peran dan kedudukan pendidikan agama (Islam), baik sebagai proses maupun sebagai lembaga.

Untuk melaksanakan sistem pendidikan nasional tersebut ada beberapa program yang harus dilaksanakan oleh pendidikan kita. Armai Arief menyebutnya ada lima agenda yang mendesak yaitu: Pertama, perlunya mempersiapkan lembagalembaga pendidikan dan pelatihan di daerah yang meliputi Sumber Daya Manusia (SDM), organisasi, fasilitas dan program kerjasama antarlembaga di daerah. Kedua, perlunya debirokratisasi penyelenggaraan pendidikan dengan merestrukturisasi departemen pusat agar lebih efisien, dan secara berangsur-angsur memberikan otonomi dalam penyelenggaraan pendidikan pada tingkat sekolah (otonomi lembaga). Ketiga, desentralisasi penyelenggaraan pendidikan nasional dilakukan secara bertahap, mulai dari tingkat provinsi, kabupaten/kota dengan mempersiapkan SDM, dana, sarana dan prasarana yang memadai pada daerah Tingkat Dua tersebut. Keempat, perlunya penghapusan berbagai peraturan perundang-undangan yang menghalangi inovasi dan eksperimen menuju sistem pendidikan yang berdaya saing di masa depan. Kelima, mengadakan revisi UU Sistem Pendidikan Nasional beserta peraturan perundangan pelaksanaannya. Revisi ini mencakup otonomi bagi sekolah untuk mengatur diri sendiri, peran masyarakat untuk ikut menentukan kebijakan pendidikan yang diwadahi dalam bentuk Dewan Sekolah, fungsi pengawasan diarahkan untuk peningkatan profesionalisme guru, adanya otonomi guru untuk menentukan metode dan sistem evaluasi belajar, dan sebagainya

(http://makalahmajannaii.blogspot.com).

\section{APLIKASI MODEL KONSTRUKTIVISME DALAM PEMBELAJARAN PAI}

Mengapa dibutuhkan inovasi pada pembelajaran PAI ? Barangkali itu pertanyaan yang pertama kali muncul dalam benak kita. Jika kita perhatikan, selama ini metode yang digunakan oleh guru-guru dalam proses pembelajaran adalah metode pembelajaran konvensional yang hanya meliputi siswa datang, duduk, menulis materi yang telah dituliskan oleh guru di papan tulis, mendengarkan guru menjelaskan materi dan mengerjakan tugas, dengan menggunakan metode yang masih konvensioanal yaitu metode ceramah, dengan menggunakan metode ceramah cenderung pasif dalam proses pembelajaran, dan cepat bosan bila mendengarkan penjelasan dari guru, banyak siswa yang mengantuk ketika mengikuti pembelajaran.

Dari situasi pembelajaran semacam ini hampir tidak ada kesempatan bagi siswa untuk menuangkan kreativitasnya (rasa, cipta, karsa) guna mengaktualisasikan potensi dirinya untuk berinovasi, ataupun berbagi diri (sharing) untuk sedini mungkin mengoptimalkan kemampuan, mengidentifikasi, merumuskan, mendiagnosis, dan sedapat mungkin memecahkan masalah (problem (http://sunardins.blogspot.com).

Demikian juga para guru kurang atau hampir tidak dibekali dengan metodologi yang variatif untuk membelajarkan materi pelajaran secara inovatif dan pembelajaran yang aktif (active learning). Pikiran para guru selalu dipenuhi dengan upaya mengajarkan apa yang ada dalam kurikulum dan sedapat mungkin mengejar target mata pelajaran yang telah dirumuskan dalam kurikulum, mereka hampir tidak perpikir akan upaya meyakinkan siswa untuk belajar di kelas maupun di luar kelas yang memiliki relevansi dan kondisi perubahan sosial masyarakat yang ada disekitar kehidupannya. Suatu kondisi yang akan segera mereka temui setelah menyelesaikan studinya, lebih-lebih sekolah yang memiliki misi yang menyiapkan calon pelajar pada jenjang yang lebih tinggi.

Oleh sebab itu, seyogyanya sudah harus dibiasakan penggunaan model pembelajaran konstruktivisme. Sebab tanpa dasar pengalaman belajar konstruktif akan sangat sulit bagi peserta didik untuk menerapkan pengetahuan yang selama ini telah mereka pelajari dalam kehidupan nyata.

Model pembelajaran konstruktivisme nampaknya merupakan salah satu jawaban atas permasalahan tentang rendahnya mutu kualitas pembelajaran ini diharapkan lebih meningkat. Sebab, pada model pembelajaran ini keaktivan siswa atau peserta didik lebih diutamakan. Proses belajar mengajar pada model konstruktivisme lebih diwarnai student centered daripada teacher 
centered (Trianto, 2007: 106). Model konstruktivisme lebih memberdayakan kelas sebagai centered for learning, not for teaching; not teaching process but learning process. Ini sesuai dengan yang dihajatkan oleh kurikulum 2013, yaitu penilaian autenthic (otentik); penilaian proses dan hasil.

Dengan pelibatan peserta didik secara aktif dalam proses pembelajaran, maka mereka mengalami atau bahkan menemukan ilmu yang akan menjadi pengetahuan yang mempribadi. Peserta didik perlu diberi space (ruang) untuk belajar agar dapat melakukan proses eksplorasi, elaborasi, dan konfirmasi. Proses belajar yang melibatkan ketiga hal inilah (eksplorasi, elaborasi, konfirmasi) yang dalam kurikulum 2013 disebut observasi, menanya, eksperimen, asosiasi, dan komunikasi (pendekatan saintific). Kurikulum 2013 yang merupakan penyempurnaan dari kurikulum KTSP (2006), menurut penulis sudah berbasis konstruktivisme dengan pendekatan sains dan penilaian otentik di dalamnya.

Hanya saja, untuk mencapai kualitas pembelajaran yang diinginkan tersebut, maka dibutuhkan keterampilan guru dalam proses pembelajaran antara lain mencakup; keterampilan merencanakan pembelajaran, keterampilan melaksanakan pembelajaran dan keterampilan mengevaluasi proses pembelajaran baik yang akan dilaksanakan mupun yang sudah dilaksanakan.

Selama ini, model konstruktisme banyak diterapkan pada pembelajaran sains, sementara pada pembelajaran PAI belum banyak diterapkan. Namun, dapatkah model ini diterapkan dalam pembelajaran PAI? Mengingat materi PAI ada yang bersifat ta'abbud (sistem keyakinan/ aqidah) dan ada yang bersifat ta'aqqul (akal; rasional). Untuk materi PAI yang bersifat ta'aqqul, penerapan model konstruktivisme mungkin saja dapat diterapkan. Misalnya, untuk menanamkan kejujuran, model konstruktivisme dapat diterapkan. Proses eksplorasi, elaborasi dan konfirmasi dapat digunakan beserta penilaian proses dan hasil. Demikian juga bila aplikasi teori konstruktivisme masuk kedalam pembelajaran PAI di bidang Fiqh, maka proses yang akan terbentuk :

Peserta didik akan membangun atau mengkonstruksi pengetahuan tentang fiqh khususnya masalah shalat, dari hasil yang mereka dapatkan ketika mereka duduk di bangku Madrasah Ibtidaiyah atau Sekolah dasar.

Pembelajaran tentang ibadah shalat akan menjadi lebih bermakna karena peserta didik sudah mengerti walaupun masih ada juga yang belum tahu, tetapi dalam hal ini teori konstruktivisme yang diaplikasikan ke dalam pembelajaran dapat menumbuhkan respons yang positif karena stimulus yang diberikan juga pengaruhnya lebih besar. Strategi pembelajaran hukum fiqh lebih sempurna

Peserta didik dapat berinteraksi penuh dengan metode pembelajaran ibadah shalat, karena ibadah shalat tidak cukup hanya teoritis, tapi juga harus di praktekkan (http://makalahmajannaii.blogspot.com).

Dalam upaya mengimplementasikan teori belajar konstruktivisme, Tytler mengajukan beberapa saran yang berkaitan dengan rancangan pembelajaran, sebagai berikut:

a. Memberi kesempatan kepada siswa untuk mengemukakan gagasannya dengan bahasa sendiri, bila terapannya atau aplikasinya dapat membentuk bahasa peserta didik sendiri dalam hal ibadah 'amaliyah, contohnya: peserta didik diajarkan untuk berwudhu terlebih dahulu kemudian baru diajarkan tentang shalat, tentunya pelaksanaan yang demikian membuat peserta didik dapat memberikan respons positif terhadap gaya bahasa yang dia akan ungkapkan

b. Memberi kesempatan kepada siswa untuk berfikir tentang pengalamannya sehingga menjadi lebih kreatif dan imajinatif, contohnya dalam pembelajaran fiqh, peserta didik dapat diberikan kesempatan atau rehat untuk berpikir karena dari segi pengalaman praktikum mereka juga tahu, namun disini adalah bahwa selama apa yang peserta didik yakini, dan lakukan adalah benar, tetapi pada kenyataannya masih banyak juga peserta didik yang belum paham betul tentang rukun-rukun shalat, sunnat-sunnat dalam shalat dan sebagainya.

c. Memberi kesempatan kepada siswa untuk mencoba gagasan baru, dalam hal ini pendidik atau guru pada bidang studi fiqh dapat memberikan kesempatan kepada peserta didik dalam mencoba terhadap gagasan yang baru.

d. Memberi pengalaman yang berhubungan dengan gagasan yang telah dimiliki siswa,

e. Mendorong siswa untuk memikirkan perubahan gagasan mereka, 
f. Menciptakan lingkungan belajar yang kondusif

(http://makalahmajannaii.blogspot.c om).

Dari beberapa pandangan di atas, dapat disimpulkan bahwa pembelajaran yang mengacu kepada teori belajar konstruktivisme lebih menfokuskan pada kesuksesan siswa dalam mengorganisasikan pengalaman mereka. Bukan kepatuhan siswa dalam refleksi atas apa yang telah diperintahkan dan dilakukan oleh guru. Dengan kata lain, siswa lebih diutamakan untuk mengkonstruksi sendiri pengetahuan mereka melalui asimilasi dan akomodasi.

Sementara itu, untuk materi pembelajaran PAI yang bersifat ta'abbud (keimanan), model konstruktivisme tidak dapat digunakan. Sebab, wilayah ta'abbud bersifat abstrak. Namun, penyempurnaan dalam PP Nomor 65 tahun 2013 tentang standar proses pendidikan sepertinya dapat membantu menerapkan pendekatan sains pada pembelajaran PAI; melalui proses pembelajaran yang menggunakan observasi, menanya, eksperimen, asosiasi dan komunikasi. Walaupun tidak semua prosedur itu mungkin bisa dilalui oleh peserta didik ketika membahas materi PAI yang bersifat ta'abbud, tetapi setidaknya proses questioning, associating dan communicating dapat dilakukan dalam proses pembelajaran PAI.

Misi pembelajaran PAI adalah:

a. Menyelenggarakan Pendidikan Islam yang berkualitas sesuai dengan perkembangan zaman

b. Menyelenggarakan Pendidikan Islam yang mampu membentuk perilaku religius

c. Menyelenggarakan Pendidikan Islam yang mampu mencerdaskan anak bangsa dalam menghadapi tantangan

d. kehidupan masa depan (http://animasipembelajaranpai.blog spot.com).

Jika diperhatikan rumusan di atas, maka misi PAI sebenarnya adalah memperkuat aspek afeksi (afektif) dan psikomotor dalam pembelajaran di sekolah, sehingga pada gilirannya nanti dapat menafasi profesi. Oleh sebab itu, proses pembelajaran PAI di sekolah sejatinya juga dapat disetting sedemikian rupa agar wilayah afeksi menjadi lebih kuat dan berdampak pada psikomotornya. Untuk itu, guru PAI memang tidak dapat bekerja seorang diri, diperlukan kerja sama yang baik antarguru semua mata pelajaran di sekolah, bahkan dengan kepala sekolah juga seluruh civitas akademika yang ada. Sebab, wilayah afeksi dan juga psikomotor membutuhkan pembiasaan serta keteladanan. Sebagai contoh, pembelajaran kejujuran tidak bisa dilakukan oleh guru PAI seorang diri, tetapi membutuhkan bantuan (kerja sama) dengan guru-guru mata pelajaran lainnya, karena untuk menanamkan kejujuran dibutuhkan "modeling" (teladan; figure), dan teladan itu tidak dilihat peserta didik hanya pada guru PAI.

\section{KESIMPULAN}

Model pembelajarn konstruktivisme adalah sebuah model pembelajaran yang berbasis teori konstruktivistik. Yaitu sebuah teori yang berasumsi bahwa pengetahuan bukanlah sesuatu yang sudah jadi, dan belajar bukanlah sebuah kegiatan transfer pengetahuan dari guru kepada peserta didik. Menurut konstruktivistik, pengetahuan adalah suatu bentukan yang terusmnerus dari orang yang belajar dengan setiap kali mengadakan reorganisasi karena adanya pemahaman yang baru. Belajar adalah sebuah proses "Membangun (membentuk)" pengetahuan dalam diri peserta didik, dan hal itu erat kaitannya dengan interaksi pada lingkungan sekitar serta pengalamannya sendiri. Pendidik berperan sebagai mediator dan fasilitator, agar proses belajar yang dilakukan oleh peserta didik dapat berjalan dengan baik. Pembelajaran PAI di sekolah, terutama jenjang pendidikan dasar dan menengah memiliki signifikansi yang besar. Rumusan tujuan pendidikan nasional dalam UU Sisdiknas Nomor 20 tahun 2003 mencerminkan bahwa Negara kita menempatkan agama sebagai "Core" yang akan membingkai semua mata pelajaran yang ada di sekolah. Dapat juga dikatakan agama sebagai nafas bagi profesi. Pembelajaran PAI sejatinya memiliki kekuatan pada aspek afeksi (afektif), dan psikomotor, sehingga target pembelajaran PAI di sekolah adalah bagaimana agama dalam diri anak dapat menafasi profesinya. Dengan kata lain, PAI di sekolah dapat membentuk anak yang memiliki perilaku profesi (professional), tetapi nafasnya agama (Islami). Ini yang menjadi tantangan para guru PAI di sekolah. Dalam rangka mewujudkan target tersebut, maka pembelajaran PAI perlu disetting sedemikian rupa. Salah satunya adalah menggunakan pendekatan saintific, seperti yang mendasari model konstruktivisme.

\section{DAFTAR PUSTAKA}


Abbas dan Suyanto. 2004. Wajah dan Dinamika Pendidikan Anak Bangsa. Yogyakarta: Adicita Karya Nusa.

Adisusilo, Sutarjo. 2012. Pembelajaran Nilai karakter: Konstruktivisme dan VCT sebagai Inovasi Pendekatan Pembelajaran Afektif. Jakarta: Rajawali Pers.

Baharun, H., 2017. Pengembangan Kurikulum; Teori dan Praktik (Konsep, Prinsip, Pendekatan dan Langkah-langkah Pengembangan Kurikulum PAI. CV Cantrik Pustaka, Yogyakarta.

Baharun, H., 2016. Penilaian Berbasis Kelas pada Pembelajaran Pendidikan Agama Islam di Madrasah. Model. J. Progr. Stud. PGMI 3, 205-2016.

Baharun, H., 2017. Pengembangan Kurikulum; Teori dan Praktik (Konsep, Prinsip, Pendekatan dan Langkah-langkah Pengembangan Kurikulum PAI. CV Cantrik Pustaka, Yogyakarta.

Baharun, H., 2016. Penilaian Berbasis Kelas pada Pembelajaran Pendidikan Agama Islam di Madrasah. Model. J. Progr. Stud. PGMI 3, 205-2016.

Baharun, H., \& Mundiri, A. (2011). Metodologi Studi Islam: Percikan Pemikiran Tokoh Dalam Membumikan Agama. Ar-Ruzz Media (1st ed.). Yogyakarta: Ar-Ruzz Media.

Aunurrahman. 2010. Belajar dan Pembelajaran, Bandung: Alfabeta.

Bahan TOT Kurikulum 2013. 2013. Bandung.

Budiningsih, Asri C. 2012. Belajar dan Pembelajaran. Jakarta: Rineka Cipta.

Daradjat, Zakiah. 1984. Dasar-Dasar Agama Islam: Buku Teks PAI pada Perguruan Tinggi Umum. Jakarta: Bulan Bintang.

1991. Ilmu Pendidikan Islam. Jakarta: Bumi Aksara.

2001. Metodik Khusus Pengajaran Agama Islam.Jakarta: Bumi Aksara.
Islam, S., 2017. Karakteristik Pendidikan Karakter; MenjawabTantangan Multidimensional Melalui Implementasi Kurikulum 2013 1, 89-101.

Islam, S., 2017. Karakteristik Pendidikan Karakter; MenjawabTantangan Multidimensional Melalui Implementasi Kurikulum 2013 1, 89-101.

Majid, Abdul dan Dian Andayani. 2004. Pendidikan Agama Islam Berbasis Kompetensi: Konsep dan Implementasi Kurikulum. Bandung: Rosdakarya.

Muhaimin. 2007. Pengembangan Kurikulum Pendidikan Agama Islam di Sekolah. Madrasah, dan Perguruan Tinggi. Jakarta: Raja Grafindo Persada.

Ruseffendi. 1988. dalam http:// model pembelajaran- konstruktivisme Riyanto, Yatim. 2012. Paradigma Baru Pembelajaran: sebagai Referensi bagi Pendidik dalam Implementasi Pembelajaran yang Efektif dan Berkualitas. Jakarta: Kencana.

Rusman. 2013. Model - Model Pembelajaran: Mengembangkan Profesionlisme Guru. Jakarta: Rajawali Pers.

Mundiri, A. (2017). Organizational Culture Base On Total Quality Management In Islamic Educational Institution. ADRI International Journal Of Islamic Studies and Social Sciences, 1(1), 1-11.

Mundiri, A., \& Zahra, I. (2017). Corak Representasi Identitas Ustadz dalam Proses Transmisi Pendidikan Karakter di Pesantren. Jurnal Pendidikan Islam, Vol. 2, No, 21-35.

Slameto. 2003. Belajar dan Faktor-Faktor yang Mempengaruhinya.Jakarta: Rineka Cipta.

Standar Nasional Pendidikan (SNP). 2006. Jakarta: Asa Mandiri. Trianto. 2007. Model-Model Pembelajaran Inovatif Berorientasi Konstrutivistik: KonsepLandasan Teoritis-Praktis dan Implementasinya. Jakarta: Prestasi Pustaka.

2012. Model Pembelajaran Terpadu: Konsep, Strategi dan Implementasinya dalam Kurikulum Tingkat Satuan Pendidikan (KTSP). Jakarta: Bumi Aksara.

Wilis, Ratna. 2002. Teori-Teori Belajar dan Pembelajaran. Jakarta: Erlangga.

http. Direktori FIP/JUR/administrasi pendidikan/udin saefudin saud/

http://journa1424.wordpress.com/2013/02/10/ dasar-yuridis-pendidikan-dasar-dan- 
implikasinya-dalam-kebijakanpemerintah/

http://sunardins.blogspot.com/2012/09/ inovasi-pembelajaran-pendidikanagama.html,

http://makalahmajannaii.blogspot.com/ 2012/07/teori-belajar-

konstruktivisme.

html,http://ibnsyam.blogspot.com/2012

/05/hakikat-dan-metodologipembelajaran-pai.html,

http://anananga.blogspot.com/2011/01/ pendidikan-agama-dan-

keagamaan.html,

http://www.bintangbangsaku.com/artike 1/standar-proses-permendiknas-no41-tahun-2007,

http://isyemetriah.blogspot.com/diakses jum'at, 